\title{
ANTIOXIDANT ACTIVITY DURING STORAGE OF APPLES SUBJECTED TO IRRADIATION
}

\author{
Atividade antioxidante durante o armazenamento de maçãs submetidas a irradiação
}

\author{
Camila Argenta Fante ${ }^{1}$, Heloísa Helena de Siqueira Elias ${ }^{2}$, Paôla de Castro Henrique ${ }^{2}$, \\ Ana Carolina Vilas Boas ${ }^{2}$, Luiz Carlos de Oliveira Lima ${ }^{2}$
}

\begin{abstract}
Nowadays, the number of studies about fruit conservation as well as the benefits of consumption of foods rich in antioxidant compounds was increased. This study aimed to quantify antioxidant compounds and their activity and to evaluate the physical and chemical changes during the post-harvest storage of Eva's apple cultivars that were subjected to gamma irradiation at doses of $0 ; 0.5 ; 1.0$ and $1.5 \mathrm{kGy}$. The antioxidant activity was measured by the 2.2-diphenyl-1-picrylhydrazyl (DPPH) and the $\beta$-carotene/linolenic acid methods. Levels of total phenolics, ascorbic acid, color, and soluble solids were evaluated. The results showed that, regardless of the irradiation dose, there was an increase in \% SRL during post-harvest storage of Eva's apples. Low irradiation doses were able to preserve the phenolic compounds, maintain the ascorbic acid levels and avoid an increase in the soluble solids content.
\end{abstract}

Index terms: Postharvest; storage; antioxidants; food quality.

\section{RESUMO}

Nas últimas décadas, diversos estudos têm demonstrado o interesse pela conservação de frutas e, também, pelos benefícios do consumo de alimentos ricos em compostos com atividade antioxidante. O presente estudo foi realizado com o objetivo de quantificar os compostos e a atividade antioxidante e analisar fatores físico-químicos, durante o armazenamento pós-colheita de maçãs da cultivar Eva submetidas à irradiação gama nas doses de 0;0,5;1,0 e 1,5 kGy. A atividade antioxidante foi medida pelos métodos de 2,2-difenil-1-picril-hidrazila (DPPH) e de $\beta$-caroteno/ácido linolenico. Foram avaliados os teores de compostos fenólicos totais, ácido ascórbico, cor e teor de sólidos solúveis. Os resultados mostraram que, independentemente da dose de irradiação, houve um aumento em \% SRL, durante o armazenamento pós-colheita das maçãs de Eva. Baixas doses de irradiação foram capazes de preservar os compostos fenólicos, manter os níveis de ácido ascórbico e evitar um aumento no teor de sólidos solúveis.

Termos para indexação: Pós-colheita; armazenamento; antioxidantes; qualidade de alimentos.

\section{INTRODUCTION}

Pomiculture has shown a gradual and linear growth, and the search for disease-resistant varieties with good agronomic and technological characteristics has made available a wide variety of cultivars to producers. However, little is known about the behavior of the Eva's apple cultivar, and studies to understand its behavior are needed. This cultivar has a low requirement for cold temperature storage and has therefore been successfully grown in southeastern Brazil (Hauagge; Tsuneta, 1999).

Antioxidants are naturally present in fruits; each plant species contains high concentrations of a specific group of antioxidants. Apples, which contain healthbeneficial compounds such fiber and vitamins, are one of the best sources of antioxidants and phenolic compounds, which vary among different apple cultivars (Napolitano et al., 2004; Lata; Przerdzka; Binkiwska et al., 2005; Pieniz et al., 2009).

The antioxidant activity of a food is a result of the action of each of its antioxidants, which can interact and produce synergistic or inhibitory effects (Lee et al., 2003). Among the various food components with antioxidant activity, the most important are the phenolic compounds and ascorbic acid. Phenolic compounds (or polyphenols), which consist of a heterogeneous group of substances found in different concentrations in plant foods, are of great interest due to their antioxidant potential (Scalbert; Williamson, 2000; Lopes et al., 2012).

The antioxidant activity of bioactive compounds is related to their structure and concentration in the plant food. In turn, the concentration of these bioactive compounds is largely influenced by genetic factors, ripeness degree, environmental and processing, storage

\footnotetext{
${ }^{1}$ Universidade Federal de Minas Gerais/UFMG - Departamento de Alimentos - Avenida Antônio Carlos - 6627 - Pampulha - $31270-901$ - Belo Horizonte - MG - Brasil - camilafante@ufmg.br

${ }^{2}$ Universidade Federal de Lavras/UFLA - Departamento de Ciência dos Alimentos/DCA - Lavras - MG - Brasil

Received in september 17, 2014 and approved in january 15, 2015
} 
time and packaging method (Amakura et al., 2000; Kaur; Kapoor, 2001; Kiralp; Toppare, 2006; Lima et al., 2009; Queiroz et al., 2011).

Irradiation has emerged as an alternative method for the preservation of fruits and vegetables without the use of chemical preservatives (Hussain et al., 2012). During irradiation, foods are exposed to a controlled amount of ionizing radiation for a specific amount of time. This preservation method, which has been studied to improve food safety since the $1950 \mathrm{~s}$, offers advantages to the industry, retailers and consumers (Park et al., 2010).

The determination of the optimal dose of irradiation for each product is very important because, if the dose is higher than necessary can promote unfavorable changes in the quality of irradiated products (Azelmat et al., 2006). Gamma irradiation is effective in reducing bacterial and rust contamination, inactivating pathogens present in fresh produce, and decreasing the fruit ripening and decomposition processes (Sendra et al., 1996; Niemira et al., 2003; Baskaran; Devi; Nayak, 2007; Guimarães et al., 2012). Irradiation can inhibit senescence, ensure food safety, and expand product shelf life (Farkas, 1998; Deruiter; Dwyer, 2002; Bari et al., 2004; Kamat et al., 2005; Shashidhar et al., 2007; Niemira, 2008). Moreover, since the microstrucural and rheological properties within the values associated with quality, gamma irradiation does not change the determining characteristics for product acceptance (Guimarães et al., 2013). Thus, this preservation method is effective during the post-harvest storage of many perishable products. Moreover, the combination of different preservation methods can result in improvements in the product. For example, gamma irradiation and a cooling treatment can reduce the level of microbial contamination and improve product shelf life (Hussain et al., 2010).

The present study aimed to quantify antioxidants and their activity in the Eva's apple cultivar and to evaluate the physical and chemical changes that occur during the post-harvest storage of an Eva's apple cultivar that was subjected to gamma irradiation.

\section{MATERIAL AND METHODS}

\section{Sample preparation}

Eva's apples were harvested during an optimal marketing period (november) in a commercial garden at Barbacena, Minas Gerais. The samples were harvested and selected for their marketable appearance and absence of injuries or diseases. Following harvest, the apples were sanitized for 10 minutes with $100 \mathrm{mg} \mathrm{L}^{-1}$ sodium hypochlorite.

\section{Experimental design}

The study was carried out using fruits from the 2009/2010 season and different doses of gamma irradiation. Harvested and sanitized apples were randomly divided into four groups and stored in cleaned Styrofoam boxes at $8 \pm 3{ }^{\circ} \mathrm{C}$. The Styrofoam boxes containing the fruits were sent to the National Nuclear Energy Center (CDTN) at Belo Horizonte, where each group was subjected to a different dose of gamma irradiation $(0,0.5,1.0$ or $1.5 \mathrm{kGy})$. The source used was $\mathrm{Co}^{60}$ and the fruit were exposed to pre-defined times according to the dose tested. After the irradiation treatments, the fruits were stored at cold temperatures $\left(0.5 \pm 0.5^{\circ} \mathrm{C}\right)$ for 135 days; the antioxidant amounts and activities were assessed every 45 days during the post-harvest storage. We used a completely randomized design ( $4 \times 3)$, with five replicates per treatment, and each treatment consisted of five fruits.

\section{Measurements}

For the assessment of antioxidant activity (DPPH and $\beta$-carotene/linolenic acid methods) and the total phenolic compound concentration, $10 \mathrm{~g}$ of each sample was homogenized at room temperature in $20 \mathrm{~mL} \mathrm{50 \%}$ methyl alcohol. After an hour, the mixture was centrifuged (14.000 rpm for 17 minutes), and the supernatant was collected. The pellet was then homogenized in $20 \mathrm{~mL}$ of $70 \%$ acetone; following one hour, it was re-centrifuged (14.000 rpm for 17 minutes). The supernatants obtained from the first and last centrifugations were pooled, and the volume was adjusted to $50 \mathrm{~mL}$ with distilled water (Rufino et al., 2007).

The antioxidant activity was determined based on the extinction of absorption by the 2.2-diphenyl-1picril hydrazyl (DPPH) radical (Rufino et al., 2007). Approximately $0.5 \mathrm{~mL}$ of $60 \mu \mathrm{M}$ DPPH was added to each extract. The control sample consisted of $0.5 \mathrm{~mL}$ of methanol with $0.5 \mathrm{~mL}$ of $60 \mu \mathrm{M} \mathrm{DPPH}$. After 30 minutes, absorbance was measured in a Beckman $640 \mathrm{~B}$ spectrophotometer at $515 \mathrm{~nm}$, and the results were expressed as percentage of free radical scavenging ( $\% \mathrm{SRL}$ ) according to Equation 1:

$\% \mathrm{SRL}=(\mathrm{Ac}-\mathrm{Am}) \times 100 / \mathrm{Ac}$

where $\mathrm{Ac}=$ control sample absorbance and $\mathrm{Am}=$ sample absorbance.

The determination of the total antioxidant activity by the $\beta$-carotene/linolenic acid method was performed using $0.4 \mathrm{~mL}$ extract to which $5.0 \mathrm{~mL}$ of an emulsion 
(containing $40 \mu \mathrm{L}$ linoleic acid 99\%, $530 \mu \mathrm{g}$ Tween 40 90\% and $20 \mathrm{mg} \beta$-carotene $93 \%$, all from Sigma) was added. The absorbance was promptly measured in a spectrophotometer at $470 \mathrm{~nm}$. Tubes were then incubated at $40{ }^{\circ} \mathrm{C}$. After 120 minutes (during which oxidation reactions take place), the absorbance was measured again. The results were expressed as percentage of oxidation inhibition. The absorbance reduction in the absence of antioxidants (Equation 2) was considered to be $100 \%$.

The absorbance reduction of the system without antioxidants (Equation 2) was taken as $100 \%$ (Rufino et al., 2006).

Absorbance reduction $=\mathrm{Abs}_{\text {initial }}-\mathrm{Abs}_{\text {final }}$

The oxidation percentage was calculated by dividing the reduction in the sample absorbance by the reduction in the system absorbance (Equation 3). To obtain the protection percentage, the oxidation percentage of each sample was subtracted from 100 (Equation 4).

Oxidation $\%=\frac{\left[(\text { Reduction Abs })_{\text {sample }} \times 100\right]}{(\text { Reduction Abs })_{\text {system }}}$

Protection $\%=100-($ Oxidation $\%)$

For the determination of total phenolic compound concentration, $2.5 \mathrm{~mL}$ of $10 \%$ Folin-Ciocalteu and 2 $\mathrm{mL}$ of $4 \%$ sodium carbonate solutions were added to $0.5 \mathrm{~mL}$ of sample extract. The tubes were shaken and then kept in the dark for 2 hours. The blue color that appeared as a result of the Folin-Ciocalteu reagent being reduced by the phenolic compounds was measured in a spectrophotometer at $750 \mathrm{~nm}$. The phenolic concentration of the samples was determined from a gallic acid standard curve. The results were expressed as $\mathrm{mg}$ of gallic acid equivalent per $100 \mathrm{~g}$ of sample (mg EAG.100 $\mathrm{g}^{-1}$ ) (Waterhouse, 2002).

The ascorbic acid concentration was determined by a colorimetric method using 2,4-dinitrophenyl hydrazine and a Beckman 640 B spectrophotometer equipped with a computerized system; the results were expressed as $\mathrm{mg}$ of ascorbic acid per $100 \mathrm{~g}^{-1}$ of pulp (Strohecker; Henning, 1967).

The background color of the epidermis was measured on opposite sides of the fruit using a Minolta CR 400 colorimeter, set to a CIE L*, a*, b* mode. The coordinate $\mathrm{L}^{*}$ is as lighter or darker the sample, with values ranging from 0 (completely black) to 100 (pure white). Soluble solids were assessed using a digital handheld pocker refractometer (Atago, Pocket PAL-1), the results were expressed as ${ }^{\circ}$ Brix according to the standard method (Association of Official Analytical Chemists AOAC, 2005).

\section{Statistical analyses}

The results were analyzed by one-way analysis of variance, and the means were compared using Tukey test at the $5 \%$ probability level using the program $\mathrm{R}$ Development Core Team software (R Development Core Team, 2010).

\section{RESULTS AND DISCUSSION}

Before the gamma irradiation, five samples from six fruits were analyzed for baseline characteristics. The fruits had a firmness of $47.36 \mathrm{~N}$ (unshelled), a soluble solid content of $11.5^{\circ} \mathrm{Brix}$, a titratable acidity of $0.436 \%$ malic acid, an epidermis background color $\mathrm{L}^{*}$ value equal to 77.29 , a Chroma of $40.3^{\circ}$ and a Hue angle of $99.78^{\circ} \mathrm{H}$.

Foods that naturally contain antioxidants are interesting because of their nutritional potential and therapeutic effects (Rufino et al., 2009; Lopes et al., 2012). The antioxidant activity, assessed by the DPPH method, revealed a significant increase in the percentage of free radical sequestration during storage to control fruits and treated with doses of 0.5 and $1.5 \mathrm{kGy}$. However, in fruits that were treated with $1.0 \mathrm{kGy}$, there was no change in antioxidant activity during storage (Table 1). A decrease in the protection percentage, measured by the $\beta$-carotene/linolenic acid method, was obtained in the control and $0.5 \mathrm{kGy}$-irradiated fruits during storage (Table 1).

The data suggest an increase in free radical sequestration during storage, independent of the irradiation treatment. Similar results were obtained by Camargo et al (2011) in IAC-Tatu's peanut cultivars. However, the authors of this study obtained a higher antioxidant activity in IAC-Runner 886 peanuts that were treated with a 15.0 kGy dose of irradiation (Camargo et al., 2011). Authors who studied irradiated juices at doses of 1.0, 3.0 and 5.0 $\mathrm{kGy}$ noted either no change or a significant increase in antioxidant activity, which is essential for the product's preservation (Lee et al., 2009). Similarly, in a study with irradiated alfalfa seeds, the authors noted that irradiation had no effect on the nutritional value but was able to increase the antioxidant activity (Fan; Thayer; Sokorai, 2004). Moreover, Queiroz et al (2011) working with cashews, found that storage did not affect the antioxidant activity of this fruit. 
Table 1: Total antioxidant activity (TAA) obtained by two different methods in apples cv. Eva stored for 45, 90 or 135 days $\left(0.5 \pm 0.5^{\circ} \mathrm{C}\right)$ and subjected to different gamma irradiation doses at the beginning of the storage.

\begin{tabular}{ccccccc}
\hline \multirow{2}{*}{$\begin{array}{c}\text { Irradiation dose } \\
(\mathrm{kGy})\end{array}$} & \multicolumn{3}{c}{ TAA- DPPH (\% SRL) } & \multicolumn{3}{c}{ TAA - $\beta$-carotene/linolenic acid (\% Protection) } \\
\cline { 2 - 6 } & 45 & 90 & 135 & 45 & 90 & 135 \\
\hline 0 & $45.4 \mathrm{Ab}$ & $57.6 \mathrm{Aa}$ & $59.0 \mathrm{Aa}$ & $73.7 \mathrm{Aa}$ & $70.7 \mathrm{Ab}$ & $68.0 \mathrm{Abc}$ \\
0.5 & $27.6 \mathrm{Bb}$ & $31.9 \mathrm{Dab}$ & $36.2 \mathrm{Ba}$ & $70.1 \mathrm{Ba}$ & $67.9 \mathrm{Ba}$ & $65.7 \mathrm{Bb}$ \\
1.0 & $41.3 \mathrm{Aa}$ & $42.7 \mathrm{Ca}$ & $37.0 \mathrm{Ba}$ & $71.6 \mathrm{Aa}$ & $67.5 \mathrm{Ba}$ & $69.2 \mathrm{Aa}$ \\
1.5 & $38.5 \mathrm{Ac}$ & $48.1 \mathrm{Bb}$ & $58.9 \mathrm{Aa}$ & $67.5 \mathrm{Ca}$ & $69.1 \mathrm{ABa}$ & $68.5 \mathrm{Aa}$ \\
\hline
\end{tabular}

Letters represent a significant difference in the row (lowercase letters) or in the column (uppercase letters) by the Tukey test at $5 \%$ error probability.

The analysis of the antioxidant activity at different irradiation doses, were found that after 45 days of storage, the control fruits and those treated with the highest irradiation doses had the highest percentage of free radical sequestration and protection percentage as determined by the $\beta$-carotene/linolenic acid method. After 90 days of post-harvest storage, the same results were obtained. After 135 days of refrigerated storage $\left(0.5 \pm 0.5^{\circ} \mathrm{C}\right)$, the control fruits and those treated with the highest irradiation (1.5 $\mathrm{kGy}$ ) showed the best results with respect to \% SRL and $\%$ protection.

The antioxidant activity, as determined by the $\beta$-carotene/linolenic acid method, measures the ability of an antioxidant to protect the sample from lipid oxidation; therefore, the method determines the ability to inhibit free radicals generated during the peroxidation of linoleic acid. The $\beta$-carotene/linolenic acid method differs from the DPPH method in that it is based on the electron transfer from an antioxidant to a free radical(Duarte-Almeida et al., 2006).

A study that assessed the antioxidant activity of Brazilian fruits revealed that plums and Spondias tuberosa have intermediate levels of oxidation inhibition when assessed by the $\beta$-carotene/linolenic acid method (Rufino et al., 2010). Similarly, Eva's apples have an intermediate level of oxidation inhibition because they showed, a protection ranging from 60 to $73 \%$.

The phenolic compound concentrations are shown in Table 2. Similar to the control fruit, total phenolics decreased in the samples that had been subjected to the $1.0 \mathrm{kGy}$ irradiation dose. Already the fruits subjected to the $0.5 \mathrm{kGy}$ dose showed an increase in total phenolic concentration during storage; we did not detect a significant difference in the samples subjected to the highest dose (1.5 $\mathrm{kGy}$ ). However, the fruits that had not been irradiated had a more pronounced decrease in total phenolic concentration at the end of the post-harvest storage. Moreover, the fruit responses were inversely proportional to the applied dose; better responses were obtained in the fruits that had been subjected to the lowest doses of irradiation.

In general, the total phenolic compounds concentration remains relatively stable during storage, but some individual compounds may vary (Awad; Jager, 2000; Awad; Jager, 2003). Moreover, processing conditions and prolonged storage promote both chemical and enzymatic oxidation of phenolic compounds, contributing to its reduction (Lee et al., 2003). Studies involving bioactive compounds and antioxidant activity in fruits have shown that both Myrciaria cauliflora and Euterpe oleracea Mart. have intermediate levels of these bioactive compounds (100 to 500 EAG per 100 $\mathrm{g}$ of pulp). Thus, the data suggest that the Eva's apple cultivar has intermediate levels of phenolic compounds.

Ascorbic acid decreased with storage time, except in the $0.5 \mathrm{kGy}$-irradiated fruits (Table 2). The treatment with the highest irradiation dose resulted in higher ascorbic acid concentrations at 45 and 90 days of storage. In addition, at 45 days, the $1.0 \mathrm{kGy}$ and $1.5 \mathrm{kGy}$ irradiation doses resulted in similar ascorbic acid concentrations. The 0.5 $\mathrm{kGy}$ and control groups had the highest of ascorbic acid concentration, suggesting that low doses of irradiation during the post-harvest storage are more effective in maintaining ascorbic acid levels. Lima et al (2009) found that ascorbic acid content was higher in samples of "buriti fruit" subjected to irradiation. Although ascorbic acid is important to human health, this compound represents a small fraction of the apple's antioxidant activity (Lee et al., 2003; Boyer; Brown; Liu, 2004).

The background color ( $\mathrm{L}^{*}$ value) and soluble solids (SS) content are shown in Table 3. There were no statistically significant differences in $\mathrm{L}^{*}$ values according to irradiation doses and storage time. 
Table 2: Phenolic compound and ascorbic acid concentrations in apple cv. Eva stored for 45, 90 or 135 days $(0.5 \pm$ $0.5^{\circ} \mathrm{C}$ ) and subjected to different gamma irradiation doses at the beginning of the storage.

\begin{tabular}{ccccccc}
\hline \multirow{2}{*}{$\begin{array}{c}\text { Irradiation dose } \\
(\mathrm{kGy})\end{array}$} & \multicolumn{3}{c}{ Phenolic compounds (mg EAG.100 $\left.\mathrm{g}^{-1}\right)$} & \multicolumn{3}{c}{ Ascorbic Acid (mg.100 $\mathrm{g}^{-1}$ pulp) } \\
\cline { 2 - 6 } & 45 & Storage (days) & \multicolumn{3}{c}{ Storage (days) } \\
\hline 0 & $206 \mathrm{Aa}$ & $177 \mathrm{Ab}$ & $130 \mathrm{Dc}$ & $26.5 \mathrm{Ba}$ & $24.7 \mathrm{Bab}$ & $22.9 \mathrm{ABb}$ \\
0.5 & $145 \mathrm{Db}$ & $142 \mathrm{Cb}$ & $175 \mathrm{Aa}$ & $25.4 \mathrm{Ba}$ & $25.0 \mathrm{Ba}$ & $24.5 \mathrm{Aa}$ \\
1.0 & $180 \mathrm{Ba}$ & $181 \mathrm{Aa}$ & $141 \mathrm{Cb}$ & $31.2 \mathrm{Aa}$ & $24.1 \mathrm{Bb}$ & $16.6 \mathrm{BCc}$ \\
1.5 & $165 \mathrm{Ca}$ & $161 \mathrm{Ba}$ & $160 \mathrm{Ba}$ & $30.1 \mathrm{Aa}$ & $30.6 \mathrm{Aa}$ & $21.9 \mathrm{Bb}$ \\
\hline
\end{tabular}

Note: Letters represent a significant difference in the row (lowercase letters) or in the column (uppercase letters) by the Tukey test at $5 \%$ error probability.

Table 3: Background color ( $\left.\mathrm{L}^{*}\right)$ and SS content in apple cv. Eva stored for 45,90 or 135 days $\left(0.5 \pm 0.5^{\circ} \mathrm{C}\right)$ and subjected to different gamma irradiation doses at the beginning of the storage.

\begin{tabular}{ccccccc}
\hline \multirow{2}{*}{$\begin{array}{c}\text { Irradiation dose } \\
(\mathrm{kGy})\end{array}$} & \multicolumn{3}{c}{$\mathrm{L}^{*}$} & Storage (days) & \multicolumn{3}{c}{ SS ( $\left.{ }^{\circ} \mathrm{Brix}\right)$} \\
\cline { 2 - 6 } & 45 & 90 & 135 & 45 & 90 & 135 \\
\hline 0 & $74.6 \mathrm{Aa}$ & $73.6 \mathrm{Aa}$ & $73.0 \mathrm{Aa}$ & $13.0 \mathrm{Aa}$ & $14.0 \mathrm{Aab}$ & $14.6 \mathrm{ABb}$ \\
0.5 & $73.4 \mathrm{Aa}$ & $74.3 \mathrm{Aa}$ & $73.2 \mathrm{Aa}$ & $12.5 \mathrm{Aa}$ & $12.8 \mathrm{Ba}$ & $13.2 \mathrm{Ba}$ \\
1.0 & $73.8 \mathrm{Aa}$ & $74.5 \mathrm{Aa}$ & $72.4 \mathrm{Aa}$ & $12.8 \mathrm{Aa}$ & $12.0 \mathrm{Ba}$ & $13.0 \mathrm{Ba}$ \\
1.5 & $73.5 \mathrm{Aa}$ & $73.3 \mathrm{Aa}$ & $71.8 \mathrm{Aa}$ & $13.3 \mathrm{Aab}$ & $12.3 \mathrm{Ba}$ & $14.0 \mathrm{Bb}$ \\
\hline
\end{tabular}

Note: Letters represent a significant difference in the row (lowercase letters) or in the column (uppercase letters) by the Tukey test at $5 \%$ error probability.

A slight increase in SS content was obtained in the control and $1.5 \mathrm{kGy}$-irradiated fruits. No significant differences were obtained for the other irradiation doses. However, the irradiated fruits had a lower SS content after 90 days of cold storage, indicating lower metabolic activity in these fruits, most likely due to the applied treatment.

\section{CONCLUSIONS}

Gamma irradiation applied after harvest of Eva's apple cultivar is able to maintain the ascorbic acid content, color and fruit quality. The highest irradiation doses showed the best results when it comes to percentage of sequestration of free radicals and percentage of protection, and the dose of $1.5 \mathrm{kGy}$ was able to keep the phenolic compounds.

\section{ACKNOWLEDGMENTS}

The authors are grateful to FAPEMIG and CAPES for their financial support and to Sítio Camará and Centro de Desenvolvimento de Energia Nuclear (CDTN/CNEN) for their support during the study.

\section{REFERENCES}

AMAKURA, Y. et al. Influence of jam processing on the radical scavenging activity and phenolic content in berries. Journal of Agricultural and Food Chemistry. 48(12):6292-6297, 2000.

ASSOCIATION OF OFFICIAL ANALYTICAL CHEMISTS - AOAC. Official methods of analysis of AOAC International (17th ed.). Gaithersburg: AOAC International, 2005.

AWAD, M.A.; DE JAGER, A. Flavonoid and chlorogenic acid concentrations in skin of 'Jonagold' and 'Elstar' apples during and after regular and ultra low oxygen storage. Postharvest Biology and Technology. 20(1):15-24, 2000. 
AWAD, M.A.; DE JAGER, A. Influences of air and controlled atmosphere storage on the concentration of potentially healthful phenolics in apples and other fruits. Postharvest Biology and Technology. 27(1):53-58, 2003.

AZELMAT, K. et al. Irradiation of 'Boufeggous' dates: Effects on chemical composition during storage. Postharvest Biology and Technology. 39(2):217-222, 2006.

BARI, M.L. et al. Irradiation to kill Escherichia coli O157:H7 and Salmonella on ready-to-eat radish and mung beans prouts. Journal of Food Protection. 67(10):2263-2268, 2004.

BASKARAN, R.; DEVI, A.U.; NAYAK, C.A. Effect of low dose gamma irradiation on the shelf life and quality characteristics of minimally processed potato cubes under modified atmosphere packaging.

Radiation Physics and Chemistry. 76(6):1042-1049, 2007.

BOYER, J.; BROWN, D.; LIU, R.H. Uptake of quercetin and quercetin 3-glucoside from whole onion and apple peel extracts by Caco-2 cell monolayers.

Journal of Agricultural and Food Chemistry. 52(23):7172-7179, 2004.

CAMARGO, A.C. et al. Efeitos da radiação gama na cor, capacidade antioxidante e perfil de ácidos graxos em amendoim (Arachis hypogaea L.) Ciência e Tecnologia de Alimentos. 31(1):11-15, 2011.

DERUITER, F.E.; DWYER, J. Consumer acceptance of irradiated foods: Dawn of a new era? Europen Food Research and Technology. 2(2):47-58, 2002.

DUARTE-ALMEIDA, J.M. et al. Avaliação da atividade antioxidante utilizando sistema $\beta$-caroteno/ ácido linoléico e método de seqüestro de radicais DPPH. Ciência e Tecnologia de Alimentos. 26(2):446-452, 2006.

FAN, X.; THAYER, D.W.; SOKORAI, K.J.B. Changes in growth and antioxidant status of alfalfas prouts during sprouting as affected by gamma irradiation of seeds. Journal of Food Protection. 67(3):561-566, 2004.
FARKAS, J. Irradiation as a method for decontaminating food: A review. International Journal of Food Microbiology. 44(3):89-204, 1998.

GUIMARÃES, I.C.O. et al. The effect of $\mathrm{Co}^{60}$ on the physical and physicochemical properties of rice. Ciência e Agrotecnologia. 36(2):210-216, 2012.

Microstructural and rheological properties of irradiated rice. Ciência e Agrotecnologia. 37(3):237-243, 2013.

HAUAGGE, R.; TSUNETA, M. IAPAR 75 - Eva, IAPAR 76 - Anabela e IAPAR 77 - Carícia: Novas cultivares de macieira com baixa necessidade em frio.

Revista Brasileira de Fruticultura. 21(3):239-242, 1999.

HUSSAIN, P.R. et al. Carboxymethyl cellulose coating and low-dose gamma irradiation improves storage quality and shelf life of pear (Pyrus Communis L. Cv. Bartlett/William). Journal of Food Science. 75(9):M586-M596, 2010.

Effect of post-harvest calcium chloride dip treatment and gamma irradiation on storage quality and shelf-life extension of Red delicious apple. Journal of Food Science and Technology. 49(4):415426, 2012.

KAMAT, A.S. et al. Effect to flow-dose irradiation on shelf life and microbiological safety of slice darrot. Journal of the Science of Food and Agriculture. 85(13):2213-2219, 2005.

KAUR, C.; KAPOOR, H.C. Antioxidants in fruits and vegetables - the millennium's health. International Journal of Food Science and Technology. 36(7):703$725,2001$.

KIRALP, S.; TOPPARE, L. Polyphenol content in selected Turkish wines, an alternative method of detection of phenolics. Process Biochemistry. 41(1):236-239, 2006

LATA, B.; PRZERDZKA, M.; BINKIWSKA, M. Great differences in antioxidant properties exist between 56 apple cultivars and vegetation seasons. Journal of Agricultural and Food Chemistry. 53(23):8970-8978, 2005. 
LEE, J.W. et al. Effect of gamma irradiation on microbial analysis, antioxidant activity, sugar content and color of ready-to-use tamarind juice during storage. Food Science and Technology. 42(1):101-105, 2009.

LEE, K.W. et al. Major phenolics in apple and their contribution to the total antioxidant capacity. Journal of Agricultural and Food Chemistry. 51(22):6516-6520, 2003.

LIMA, A.L.S. et al. Avaliação dos efeitos da radiação gama nos teores de carotenóides, ácido ascórbico e áçucares do fruto buriti do brejo (Mauritia flexuosa L.). Acta Amazonica. 39(3):649-654, 2009.

LOPES, M.M.A. et al. Bioactive compounds and total antioxidant capacity of cashew apples (Anacardium occidentale L.) during the ripening of early dwarf cashew clones. Ciência e Agrotecnologia. 34(3):325332, 2012

NAPOLITANO, A. et al. Influence of variety and storage on the polyphenol composition of apple flesh. Journal of Agricultural and Food Chemistry. 52(21):6525-6531, 2004.

NIEMIRA, B.A. Irradiation compared with chlorination for elimination of Escherichia coli O157:H7 internalized in lettuce leaves: Influence of lettuce variety. Journal of Food Science. 73(5):M208-M213, 2008.

NIEMIRA, B.A. et al. Ionizing radiation sensitivity of Listeria monocytogenes and L. innocua inoculated on endive (Cichorium endive). Journal of Food Protection. 66(6):993-998, 2003.

PARK, J.G. et al. Effects of gamma irradiation and electron beam irradiation on quality, sensory, and bacterial populations in beef sausage patties. Meat Science. 85(2):368-372, 2010.

PIENIZ, S. et al. Avaliação in vitro do potencial antioxidante de frutas e hortaliças. Ciência e Agrotecnologia. 33(2):552-559, 2009.

QUEIROZ. C. et al. Changes in bioactive compounds and antioxidant capacity of fresh-cut cashew apple.

Food Research International. 44(5):1459-1462, 2011.
R DEVELOPMENT CORE TEAM. A language and environment for statistical computing. Vienna: $\mathrm{R}$ Foundation for Statistical Computing, 2010. Retrieved from http://www.R-project.org. Access in: 2014.

RUFINO, M.S.M. et al. Bioactive compounds and antioxidant capacities of 18 non-traditional tropical fruits from Brazil. Food Chemistry. 2010. Available in: http://www.sciencedirect.com/science/article/pii/ S0308814610001172\#. Access in: 2014.

. Metodologia científica:

determinação da atividade antioxidante total em frutas pela captura do radical livre DPPH. Fortaleza: Embrapa, 2007. 4 p.

. Metodologia científica:

Determinação da atividade antioxidante total em frutas no sistema $\beta$-caroteno/Ácido Linoléico. Fortaleza: Embrapa, 2006. 4p.

Free radical-scavenging behavior of some north-east Brazilian fruits in a DPPH system. Food Chemistry. 114(2):693-695, 2009.

SCALBERT, A.; WILLIAMSON, G. Dietary intake and bioavailability of polyphenols. Journal of Nutrition. 130(8):2073S-2085S, 2000.

SENDRA, E. et al. Review: Food irradiation.-General aspects. Food Science and Technology International. 2(1):1-11, 1996.

SHASHIDHAR, R. et al. Effectiveness of radiation processing for elimination of Salmonella typhimurium from minimally processed pineapple (Ananascomosus Merr.). Journal of Food Science. 72(3):M98-101, 2007.

STROHECKER, R.L.; HENNING, H.M. Análisis de vitaminas: métodos comprobados. Madri: Paz Montalvo, 1967. 428p.

WATERHOUSE, A.L. Polyphenolics: Determination of total phenolics. In: Wrolstad, R.E. Current Protocols in Food Analytical Chemistry. New York: John Wiley and Sons, 2002. 1111-1118p. 